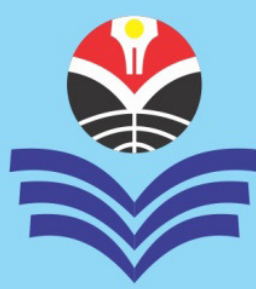

Published every March and September

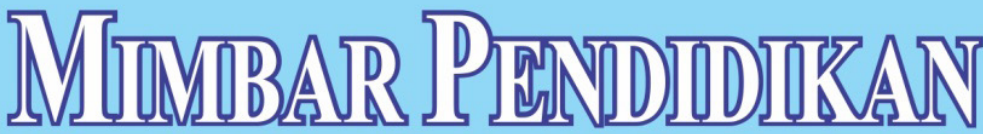

Jurnal Indonesia untuk Kajian Pendidikan

\author{
I MADE YUDA SURYAWAN, \\ I WAYAN SANTYASA \& I GEDE ARIS GUNADI
}

\title{
Keefektifan Model Problem Based Learning dan Motivasi Berprestasi Siswa dalam Pencapaian Prestasi Belajar Fisika
}

\begin{abstract}
ABSTRAKSI: Penelitian ini mendeskripsikan pengaruh interaktif antara model pembelajaran dan motivasi berprestasi terhadap prestasi belajar Fisika. Penelitian menggunakan kuasi eksperimen dengan desain pre-test dan post-test non-equivalent control group design. Populasi penelitian adalah siswa Kelas X MIPA SMAN (Matematika dan Ilmu Pengetahuan Alam, Sekolah Menengah Atas Negeri) 1 Kubutambahan di Bali, Indonesia, yang terdiri dari empat kelas atau 130 orang. Data dianalisis menggunakan analisis deskriptif dan analisis kovarian dua jalur. Hasil penelitian mengungkapkan bahwa prestasi belajar siswa diakibatkan oleh perbedaan model pembelajaran. Prestasi belajar yang lebih tinggi diraih oleh siswa yang menerima perlakuan model PBL (Problem Based Learning atau Pembelajaran Berbasis Masalah). Perbedaan prestasi belajar siswa juga diakibatkan oleh perbedaan motivasi berprestasi. Prestasi belajar yang lebih tinggi diraih oleh siswa yang memiliki MBT (Motivasi Berprestasi Tinggi). Akhirnya, ada pengaruh interaktif antara model pembelajaran dan motivasi berprestrasi terhadap prestasi belajar siswa.

KATA KUNCI: Model Pembelajaran; Prestasi Belajar; Motivasi; Matapelajaran Fisika.
\end{abstract}

ABSTRACT: "Effectiveness of the Problem Based Learning Model and Student Achievement Motivation in Gaining the Physics Learning Achievements". The research describes the interactive influence between model of learning and achievement motivation toward Physics learning achievement. The research used a quasi experimental study with pre-test and post-test non-equivalent control group design. The population of this study were the students of Class X Mathematics and Sciences at the Public Senior High School 1 Kubutambahan in Bali, Indonesia, consisted of four classes or 130 people. Data were analyzed using descriptive analysis and two-ways analysis of covariance. The results of this study reveal that the student achievement is due to the differences in learning models. Higher learning achievement was achieved by students who received treatment of PBL (Problem Based Learning) model. The differences in student achievement are due to also the differences in achievement motivation. Higher achievement of learning achieved by students who have high achievement motivation. Lastly, there are the interactive influences between learning model and achievement motivation towards the student achievement.

KEY WORD: Learning Model; Learning Achievement; Motivation; Physics Subject.

About the Authors: I Made Yuda Suryawan, S.Pd. adalah Mahasiswa Jurusan Pendidikan Fisika FMIPA UNDIKSHA (Fakultas Matematika dan Ilmu Pengetahuan Alam, Universitas Pendidikan Ganesha) di Singaraja 81116, Bali, Indonesia. Prof. Dr. I Wayan Santyasa dan Dr. I Gede Aris Gunadi adalah Dosen di Jurusan Pendidikan Fisika FMIPA UNDIKSHA di Singaraja 81116, Bali, Indonesia. Untuk kepentingan akademik, alamat emel penulis adalah: suryawanyuda96@gmail.com, santyasa@yahoo.com,dan igagunadi@gmail.com

Suggested Citation: Suryawan, I Made Yuda, I Wayan Santyasa \& I Gede Aris Gunadi. (2019). "Keefektifan Model Problem Based Learning dan Motivasi Berprestasi Siswa dalam Pencapaian Prestasi Belajar Fisika" in MIMBAR PENDIDIKAN: Jurnal Indonesia untuk Kajian Pendidikan, Volume 4(1), Maret, pp.35-54. Bandung, Indonesia: UPI [Indonesia University of Education] Press, ISSN 2527-3868 (print) and 2503-457X (online).

Article Timeline: Accepted (November 10, 2018); Revised (January 15, 2019); and Published (March 30, 2019). 


\section{PENDAHULUAN}

Fisika merupakan ilmu pengetahuan yang paling fundamental, karena merupakan dasar dari semua bidang sains. Belajar Fisika bukan hanya mencari jalan penyelesaian dari persamaan, tetapi juga mendeskripsikan belajar tentang suatu fenomena (Cohen, 2008; Sumarsono, 2009; dan Sawitri, Suparmi \& Aminah, 2016). Tujuan pembelajaran Fisika, yang tertuang dalam kerangka Kurikulum 2013, adalah untuk menguasai konsep dan prinsip serta menguasai keterampilan dalam mengembangkan pengetahuan dan sikap percaya diri sebagai bekal untuk melanjutkan pendidikan pada jenjang yang lebih tinggi, serta mengembangkan ilmu pengetahuan dan teknologi ( $c f$ Angell, Guttersurd \& Henriksen, 2007; Suparno, 2013; dan Kemendikbud RI, 2014). Jika tujuan ini dicapai oleh siswa, maka prestasi belajar siswa akan meningkat.

Prestasi belajar dipengaruhi oleh faktor internal dan faktor eksternal. Faktor eksternal, salah satunya, adalah model pembelajaran yang digunakan; sedangkan faktor internal, yang berpengaruh terhadap prestasi belajar, adalah motivasi berprestasi dalam diri siswa. Adanya motivasi berprestasi memberikan dorongan pada diri siswa untuk mencapai sukses dan menghindari kegagalan, yang menimbulkan kecenderungan perilaku berpedoman pada standar keunggulan yang telah ditetapkan (Slameto, 2003; Susilonuringsih, 2006; dan Rosnita, 2016).

Menurut Sugiyanto (2009), dan sarjana lainnya, adanya motivasi berprestasi yang tinggi dari dalam diri siswa, dan hal ini dapat menunjang pencapaian prestasi belajar yang diraih oleh siswa tersebut (Sugiyanto, 2009; Simanjuntak, 2015; dan Rosnita, 2016). Hal senada oleh R.I. Achmad et al. (2017), dan sarjana lainnya, yang menyatakan bahwa kurangnya motivasi berprestasi dalam diri menjadi dampak negatif terhadap prestasi peserta didik
(Achmad et al., 2017; Simanjuntak, 2015; dan Rosnita, 2016).

Kenyataannya, prestasi belajar siswa masih tergolong rendah. Berdasarkan penelitian yang dilakukan oleh O. Kizkapan \& O. Bektas (2017), dan sarjana lainnya, bahwa prestasi belajar yang dimiliki siswa masih tergolong rendah. Hal ini ditandai dengan kurang aktifnya siswa di kelas, sehingga siswa hanya menerima saja, sering mengalami miskonsepsi, dan siswa gagal dalam mentransfer pengetahuan mereka untuk kehidupan sehari-hari (Slameto, 2003; Arvyati, Maonde \& Noho, 2016; dan Kizkapan \& Bektas, 2017).

Penelitian berbeda, yang dilakukan oleh M.M. Melissa (2016) dan sarjana lainnya, menyatakan bahwa sebagian besar siswa kurang aktif dalam mengikuti pelajaran. Siswa cenderung lebih senang diterangkan oleh guru daripada berdiskusi kelompok, siswa masih kurang fokus dalam mengikuti diskusi, selain itu siswa hanya belajar ketika ada pekerjaan rumah atau ulangan (Slameto, 2003; Mulyono, 2011; dan Melissa, 2016).

Salah satu penyebab dari kurang optimalnya prestasi belajar siswa adalah guru hanya menggunakan metode konvensional dan kurang menghubungkan antara pembelajaran yang dipelajari dengan praktek kehidupan nyata (Sudjana, 2005; Sanjaya, 2006; dan Nuic, Sabeta \& Zejnelagic-Hajric, 2015). Hal ini didukung dengan penelitian yang dilakukan oleh E. Desnylasari, S. Mulyani \& B. Mulyani (2016), dan sarjana lainnya, yang menyatakan bahwa pembelajaran yang berlangsung lebih berpusat pada guru atau teacher centered, sebagian guru dalam pembelajaran hanya sebatas mentransfer ilmu pengetahuan (Hadi, 2007; Desnylasari, Mulyani \& Mulyani, 2016; dan Kurniawan, Miftahillah \& Nasihah, 2018).

Model pembelajaran konvensional belum mampu memberikan kontribusi besar dalam meningkatkan prestasi belajar siswa. Begitu pula penelitian yang dilakukan oleh 
Herlina, A. Kasim \& H.D. Mamu (2016), dan sarjana lainnya, yang menyatakan bahwa peran guru dalam pembelajaran masih dominan, sehingga terabaikannya kesempatan siswa untuk terlibat secara aktif dalam pembelajaran (Rusman, 2010; Mulyono, 2011; dan Herlina, Kasim \& Mamu, 2016). Hal senada didukung oleh R.D. Anazifa (2016), dan sarjana lainnya, yang menyatakan bahwa guru hanya memberikan informasi kepada siswa dengan menggunakan model konvensional. Dengan demikian, penyebab rendahnya tingkat prestasi belajar siswa, yaitu pemilihan model pembelajaran guru yang kurang tepat (Rusman, 2010; Anazifa, 2016; dan Musdiani, 2019).

Model Problem Based Learning memiliki implikasi dalam meningkatkan prestasi belajar siswa. Pembelajaran PBL (Problem Based Learning atau Pembelajaran Berbasis Masalah) merupakan salah satu model pembelajaran, termasuk pendekatan saintifik. Pemilihan model PBL diharapkan membantu peserta didik untuk mencapai keberhasilan proses belajar dan menjadikan pembelajaran lebih bermakna. Hal ini karena PBL memerlukan keterampilan guru untuk menyajikan masalah yang bersifat kontekstual (Dwi, Arif \& Sentot, 2013; Padmavathy \& Mareesh, 2013; dan Sawitri, Suparmi \& Aminah, 2016).

Model PBL juga menghendaki siswa untuk mengkontruksi pengetahuannya ke memori jangka panjang, sehingga ketika pembelajaran berlangsung, pengetahuan yang didapat melalui penyelidikan tidak semata-mata hanya digunakan untuk menyelesaikan masalah yang diberikan. Masalah yang diberikan akan menuntun siswa untuk mengkonstruksi pengetahuannya melalui penyelidikan, sehingga menemukan penyelesaian masalah yang diberikan berupa konsep-konsep ilmiah (Padmavathy \& Mareesh, 2013; Sari, Mardiyana \& Saputro, 2015; dan Sawitri, Suparmi \& Aminah, 2016).
Penelitian yang dilakukan oleh R.U. Etiubon \& A.N. Ugwu (2016), dan sarjana lainnya, juga menunjukan bahwa ada perbedaan prestasi belajar siswa, yakni antara siswa yang belajar dengan pendekatan PBL dengan siswa yang belajar dengan pendekatan ekspositori. Prestasi belajar siswa dengan pendekatan PBL lebih tinggi dibandingkan dengan pendekatan ekspositori (Etiubon \& Ugwu, 2016; Nurbaiti, Irawati \& Lichteria, 2016; dan Acep, 2018).

M.M. Melissa (2016), dan sarjana lainnya, menyatakan bahwa dengan pendekatan PBL dapat meningkatkan kemandirian dan prestasi belajar siswa (Melissa, 2016; Maydianti, Sutopo \& Chrisnawati, 2017; dan Wiyono, 2017). Hal senada juga dilakukan penelitian oleh S.K. Alpat \& T. Gunter (2016), dan sarjana lainnya, yang menyatakan bahwa siswa dengan model PBL lebih mampu memahami topik dan konsep dibandingkan dengan model ekspositori (Alpat \& Gunter, 2016; Listiani, Hidayat \& Maspupah, 2017; dan Acep, 2018). Begitu pula yang disampaikan oleh R.D. Anazifa (2016), dan sarjana lainnya, bahwa model PBL lebih efektif meningkatkan prestasi belajar dibandingkan dengan model ekspositori (Anazifa, 2016; Acep, 2018; dan Ulfa \& Asriana, 2018).

Oleh karena itu, penelitian ini akan memverifikasi keefektifan model PBL dan motivasi berprestasi dalam pencapaian prestasi belajar melalui pembelajaran Fisika. Penelitan ini sangat penting untuk dilakukan, karena tiga hal. Pertama, mendeskripsikan perbedaan prestasi belajar Fisika antara siswa yang belajar menggunakan model PBL dan model DI (Direct Instruction atau Pembelajaran Langsung). Kedua, mendeskripsikan perbedaan prestasi belajar Fisika antara siswa dengan motivasi berprestasi tinggi dan motivasi berprestasi rendah. Ketiga, mendeskripsikan pengaruh interaktif 
antara model pembelajaran dan motivasi berprestasi terhadap prestasi belajar Fisika.

\section{METODE}

Model Penelitian. Penelitian ini termasuk dalam jenis eksperimen semu, atau quasi experiment, dengan desain penelitian yang digunakan adalah pre-test - post-test nonequivalent control group design (Cook \& Campbell, 1979; Hidayat, 2012; dan Yusuf, 2014). Variabel terikat pada penelitian ini adalah prestasi belajar; variabel bebas pada penelitian ini adalah penggunaan model PBL (Problem Based Learning atau Pembelajaran Berbasis Masalah); dan variabel moderator adalah motivasi berprestasi.

Populasi dan Sampel. Populasi dalam penelitian ini adalah seluruh peserta didik Kelas X MIPA (Matematika dan Ilmu Pengetahuan Alam) di SMAN (Sekolah Menengah Atas Negeri) 1 Kubutambahan, Bali, Indonesia, yang terdiri dari empat kelas dan 130 orang. Semua kelas dipilih sebagai sampel, yaitu sebanyak empat kelas (130 orang, atau $100 \%$ dari populasi), yaitu kelas X MIPA 1 (33 orang), kelas X MIPA 2 (34 orang), kelas X MIPA 3 (30 orang), dan kelas X MIPA 4 (33 orang).

Penentuan kelas eksperimen dan kelas kontrol dilakukan secara acak, dengan menggunakan teknik random assigment, dan terpilih kelas X MIPA 1 dan kelas X MIPA 4 sebagai kelas eksperimen; serta kelas X MIPA 2 dan kelas X MIPA 3 sebagai kelas kontrol (Cook \& Campbell, 1979; Hermawan, 2012; Hidayat, 2012; dan Yusuf, 2014).

Perlakuan Penelitian. Selama penelitian berlangsung, siswa kelas X MIPA (Matematika dan Ilmu Pengetahuan Alam) 1 dan kelas X MIPA 4 menerima perlakuan menggunakan model PBL (Problem Based Learning atau Pembelajaran Berbasis Masalah); sedangkan siswa kelas X MIPA 2 dan kelas X MIPA 3 menerima perlakuan menggunakan model DI (Direct Instruction atau Pembelajaran Langsung). Sesuai dengan pernyataan di atas, perlakuan untuk kedua kelompok adalah berbeda; namun materi pembelajaran, sumber belajar, alokasi waktu pembelajaran, dan variabel lain yang mungkin berpengaruh pada varibel terikat pada kedua kelompok adalah sama (cf Wasonowati, 2014; Aidoo, Boateng \& Ofori, 2016; dan Mauludah, Roshayanti \& Sumarno, 2018).

Tanggal Penelitian. Penelitian ini dilakukan dari Februari 2018 sampai dengan April 2018 pada mata pelajaran Fisika. Materi pelajaran selama perlakuan adalah "Usaha Energi dan Momentum". Tahapan pelaksanaan penelitian dimulai dari konstruksi instrumen penelitian; uji coba instrumen hingga penentuan instrumen yang digunakan; perancangan perangkat pembelajaran berupa RPP (Rencana Pelaksanaan Pembelajaran) dan LKS (Lembar Kerja Siswa); pelaksanaan pre-test; penerapan perbedaan perlakuan berdasarkan perangkat pembelajaran yang telah dibuat; pelaksanaan post-test; dan diakhiri analisis data hingga pembahasan.

\section{Teknik Pengumpulan dan Analisis}

Data. Teknik pengumpulan data pada penelitian ini adalah menggunakan instrumen tes prestasi belajar dan angket motivasi berprestasi. Sebelum menggunakan instrumen dalam penelitian ini terlebih dahulu divalidasi isi, indeks kesukaran butir soal, indeks daya beda, dan konsistensi internal butir soal dan tes. Teknik pengumpulan data dilakukan pada kegiatan pelaksanaan pembelajaran. Instrumen tes prestasi belajar yang dikembangkan terdiri dari 15 tes essay, dengan rubrik penilaian skala 0-5; dan instrumen angket motivasi berprestasi yang dikembangkan terdiri dari 30 butir dengan rubrik penilaian skala 1-4.

Teknik analisis data dalam penelitian ini menggunakan analisis deskriptif dan ANAKOVA (Analisis Kovarian) dua jalur. Analisis kovarian memerlukan uji asumsi, yaitu uji normalitas, uji homogenitas, dan uji linieritas. Uji normalitas yang digunakan 
Tabel 1:

Data Mean dan Standar Deviasi Prestasi Belajar Fisika (Pre-Test) Siswa untuk Kelompok Eksperimen dan Kelompok Kontrol

\begin{tabular}{lcc} 
& MPBL & MDI \\
\hline MBT & $\mathrm{M}_{11}=12.3182$ & $\mathrm{M}_{21}=12.2727$ \\
& $\mathrm{SD}=8.58230$ & $\mathrm{SD}=7.74708$ \\
\hline MBR & $\mathrm{M}_{12}=7.3182$ & $\mathrm{M}_{22}=8.4091$ \\
& $\mathrm{SD}=5.73532$ & $\mathrm{SD}=5.74588$ \\
\hline
\end{tabular}

adalah Kolmogorov Test dan Shapiro-Wilk Test; uji homogenitas yang digunakan adalah Lenen's Test of Equality of Error Variance; serta uji linieritas yang digunakan adalah Test of Linierity (dalam Hermawan, 2012; Yusuf, 2014; dan Hidayat, 2017).

\section{HASIL PENELITIAN DAN PEMBAHASAN}

Hasil Penelitian. Penyebaran data prestasi belajar untuk kelompok MPBL (Model of Problem Based Learning atau Model Pembelajaran Berbasis Masalah) dengan MBT (Motivasi Berprestasi Tinggi); kelompok MPBL dengan MBR (Motivasi Berprestasi Rendah); kelompok MDI (Model of Direct Instruction atau Model Pembelajaran Langsung) dengan MBT; serta kelompok MDI dengan MBR, yang disajikan pada tabel 1. Manakala selisih nilai rata-rata pre-test dan post-test siswa masing-masing kelompok ditunjukkan dalam gambar 1 .

Skor rata-rata prestasi belajar seperti ditunjukkan pada tabel 2; dan gambar 2 untuk siswa yang belajar menggunakan MPBL (Model of Problem Based Learning atau Model Pembelajaran Berbasis Masalah) dan memiliki MBT (Motivasi Berprestasi Tinggi) dan MBR (Motivasi Berprestasi Rendah) lebih tinggi dibandingkan dengan siswa yang belajar menggunakan MDI (Model of Direct Instruction atau Model Pembelajaran Langsung).

Hasil pengujian normalitas, homogenitas, dan linieritas penyebaran data untuk prestasi belajar siswa kelompok eksperimen dan

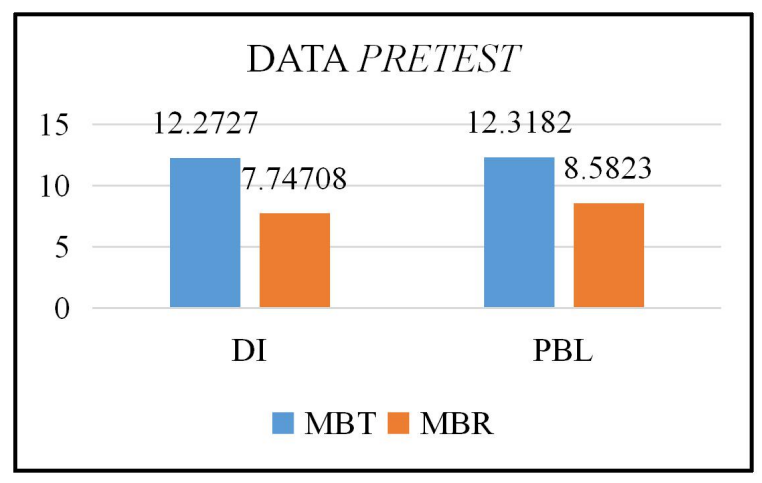

Gambar 1:

Data Prestasi Belajar Awal Fisika Siswa

kelompok kontrol, baik yang mempunyai motivasi berprestasi tinggi maupun motivasi berprestasi rendah, disajikan dalam tabel 3, tabel 4, tabel 5, dan tabel 6.

Berdasarkan tabel 3, terlihat bahwa nilai signifikansi berada di atas 0.05 untuk semua unit analisis, baik yang menggunakan statistik Kolmogorov-Smirnov Test maupun statistik Shapiro-Wilk Test. Dengan demikian dapat dinyatakan bahwa semua kelompok data yang diperoleh dalam penelitian ini berdistribusi normal (Hidayat, 2013; Oktaviani \& Notobroto, 2014; dan Basuki, 2015).

Berdasarkan tabel 4 dan tabel 5 menunjukan nilai signifikansi antar model (dua kelompok belajar) berada di atas 0.05. Signifikansi antar motivasi berprestasi (empat kelompok belajar) diperoleh juga berada di atas 0.05 . Dengan demikian, dapat disimpulkan bahwa data prestasi belajar antar model pembelajaran dan antar 
Tabel 2:

Data Mean dan Standar Deviasi Prestasi Belajar Fisika (Post-Test) Siswa untuk Kelompok Eksperimen dan Kelompok Kontrol

\begin{tabular}{lcc}
\hline & MPBL & MDI \\
\hline MBT & $\mathrm{M}_{11}=59.9545$ & $\mathrm{M}_{21}=30.000$ \\
& $\mathrm{SD}=11.62705$ & $\mathrm{SD}=13.35950$ \\
\hline MBR & $\mathrm{M}_{12}=40.9545$ & $\mathrm{M}_{22}=29.0909$ \\
& $\mathrm{SD}=15.33275$ & $\mathrm{SD}=12.49346$ \\
\hline
\end{tabular}

Tabel 3:

Rangkuman Hasil Normalitas

\begin{tabular}{lcccccc|}
\hline & \multicolumn{2}{c}{ Kolmogorov-Smirnov } & \multicolumn{3}{c|}{ Shapiro-Wilk } \\
\cline { 2 - 6 } & Statistic & Df & Sig. & Statistic & Df & Sig. \\
\hline PRE-TEST_PBL_MBT & 0.168 & 22 & 0.107 & .915 & 22 & 0.061 \\
POST-TEST_PBL_MBT & 0.101 & 22 & 0.200 & .981 & 22 & 0.928 \\
PRE-TEST_PBL_MBR & 0.183 & 22 & 0.053 & .929 & 22 & 0.115 \\
POST-TEST_PBL_MBR & 0.108 & 22 & 0.200 & .971 & 22 & 0.730 \\
PRE-TEST_DI_MBT & 0.126 & 22 & 0.200 & .949 & 22 & 0.301 \\
POST-TEST_DI_MBT & 0.100 & 22 & 0.200 & .977 & 22 & 0.865 \\
PRE-TEST_DI_MBR & 0.133 & 22 & 0.200 & .953 & 22 & 0.357 \\
POST-TEST_DI_MBR & 0.158 & 22 & 0.160 & .926 & 22 & 0.099 \\
\hline
\end{tabular}

motivasi berprestasi adalah homogen.

Berdasarkan tabel 6, pada linearity, menunjukan signifikansi yang lebih kecil daripada 0.05. Ini berarti bahwa pretest prestasi belajar berpengaruh secara signifikan terhadap prestasi belajar. Selain itu, pada deviation from linearity menunjukan signifikansi yang lebih besar daripada 0.05 . Hal ini juga menunjukan bahwa sebaran data pada masing-masing kelompok adalah linier (Hidayat, 2013; Oktaviani \& Notobroto, 2014; dan Basuki, 2015).

Setelah data diuji normalitas, uji homogenitas, dan uji liniritas, selanjutnya dilakukan pengujian hipotesis pada penelitian ini dengan menggunakan ANAKOVA (Analisis Kovarian) dua jalur. Hasil pengujian ANAKOVA disajikan pada tabel 7.

Berdasarkan rangkuman hasil ANAKOVA (Analisis Kovarian) dua jalur pada tabel 7, maka diputuskan: pertama, berdasarkan sumber pengaruh kovariat (pre-test) terhadap variabel terikat (prestasi

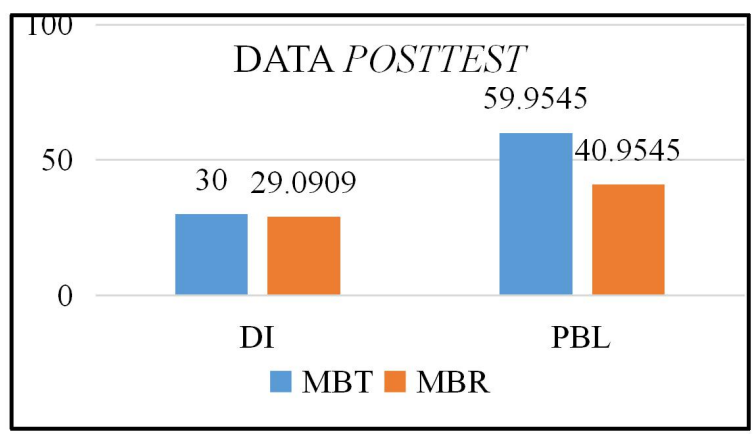

\section{Gambar 2:}

Data Prestasi Belajar Akhir Fisika Siswa

belajar) diperoleh nilai statistik $\mathrm{F}^{*}=9.819$, dengan angka signifikansi 0.02 . Ini berarti bahwa kovariabel pra-prestasi belajar berpengaruh signifikan terhadap prestasi belajar. Dengan kata lain, analisis kovarian relevan digunakan dalam penelitian ini. Kedua, berdasarkan sumber pengaruh model pembelajaran diperoleh nilai $\mathrm{F}_{\text {hitung }}\left(\mathrm{F}_{\text {MODEL }}{ }^{*}\right)$ $=62.082$, dengan angka signifikansi 0.0001 . Oleh karena angka signifikansinya lebih kecil dari 0.05, maka diputuskan $\mathrm{H}_{0}$ ditolak dan $\mathrm{H}_{\mathrm{A}}$ diterima. 
Tabel 4:

Rangkuman Hasil Pengujian Homogenitas Varians Antar Model Pembelajaran

\begin{tabular}{llc}
\hline & & Sig. \\
\hline PRE-TEST & Based on Mean & 0.431 \\
& Based on Median & 0.442 \\
& Based on Median and with Adjusted df & 0.442 \\
& Based on Trimmed Mean & 0.427 \\
\hline POST-TEST & Based on Mean & 0.223 \\
& Based on Median & 0.240 \\
& Based on Median and with Adjusted df & 0.241 \\
& Based on Trimmed Mean & 0.219 \\
\hline
\end{tabular}

Tabel 5:

Rangkuman Hasil Pengujian Homogenitas Varians Antar Motivasi Berprestasi

\begin{tabular}{llc}
\hline & & Sig. \\
\hline PRE-TEST & Based on Mean & 0.054 \\
& Based on Median & 0.057 \\
Based on Median and with Adjusted df & 0.058 \\
Based on Trimmed Mean & 0.054 \\
\hline POST-TEST & Based on Mean & 0.077 \\
& Based on Median & 0.097 \\
Based on Median and with Adjusted df & 0.097 \\
Based on Trimmed Mean & 0.075 \\
\hline
\end{tabular}

Tabel 6:

Rangkuman Hasil Linieritas

\begin{tabular}{|c|c|c|c|c|c|c|c|}
\hline & & & Sum of Squares & Df & Mean Square & $\mathbf{F}$ & Sig. \\
\hline POST-TEST* & Between & (Combined) & 9107.554 & 11 & 413.980 & 1.395 & 0.151 \\
\hline \multirow[t]{4}{*}{ PRE-TEST } & Groups & Linerity & 2500.629 & 1 & 2500.629 & 8.425 & 0.005 \\
\hline & & $\begin{array}{l}\text { Deviation from } \\
\text { Liniearity }\end{array}$ & 6606.925 & 21 & 314.615 & 1.060 & 0.411 \\
\hline & \multicolumn{2}{|c|}{ Within Groups } & 19292.446 & 65 & 296.807 & & \\
\hline & \multicolumn{2}{|l|}{ Total } & 28400.00 & 87 & & & \\
\hline
\end{tabular}

Berdasarkan hal tersebut dapat disimpulkan bahwa terdapat perbedaan prestasi belajar antar siswa yang belajar menggunakan model PBL (Problem Based Learning atau Pembelajaran Berbasis Masalah) dengan siswa yang belajar menggunakan model DI (Direct Instruction atau Pembelajaran Langsung). Signifikansi perbedaan skor rata-rata prestasi belajar antara kelompok PBL dan kelompok DI dianalisis dengan menggunakan LSD atau Least Significant Difference (Hayter, 1986; Abdi et al., 2009; dan Williams \& Abdi,
2010). Taraf signifikansi $\alpha=0.05$, jumlah sampel kelompok PBL dengan $n=44$, dan DI dengan $\mathrm{n}=44$, sehingga jumlah sampel total $\mathrm{N}=88$, jumlah kelompok model yang digunakan $\mathrm{a}=2$, diperoleh nilai statistik $\mathrm{t}_{\text {tabel }}=\mathrm{t}_{(0.025 ; 86)}=1.98793$.

Rangkuman hasil pengujian signifikansi perbedaan skor rata-rata prestasi belajar antara kelompok belajar PBL dan kelompok belajar DI disajikan pada tabel 8 .

Berdasarkan tabel 8, perbedaan skor rata-rata prestasi belajar siswa antara kelompok belajar dengan model PBL 
Tabel 7:

Rangkuman Hasil ANAKOVA Dua Jalur

\begin{tabular}{llcccc}
\hline Sorce & Type III Sum of Squares & Df & Mean Square & F & Sig. \\
\hline Corrected Model & $15164.142^{\mathrm{a}}$ & 4 & 3791.035 & 23.773 & 0.000 \\
Intercept & 32161.504 & 1 & 32161.504 & 201.680 & 0.000 \\
PRE-TEST & 1565.869 & 1 & 1565.869 & 9.819 & 0.002 \\
MODEL & 9900.176 & 1 & 9900.176 & 62.082 & 0.000 \\
MOTIVASI & 1047.047 & 1 & 1047.047 & 6.566 & 0.012 \\
MODEL * MOTIVASI & 1661.661 & 1 & 1661.661 & & \\
Error & 13235.858 & 83 & & & \multirow{2}{*}{10.420} \\
\hline Total & $\mathbf{1 6 9 2 0 0 . 0 0 0}$ & $\mathbf{8 8}$ & \multirow{2}{*}{$\mathbf{1 5 9 . 4 6 8}$} & & \\
Corrected Total & $\mathbf{2 8 4 0 0 . 0 0 0}$ & $\mathbf{8 7}$ & & & \\
\hline
\end{tabular}

Tabel 8:

Signifikansi Perbedaan Skor Rata-rata Prestasi Belajar antara Kelompok PBL dan Kelompok DI

\begin{tabular}{ccccc}
\hline (I) Model & (J) Model & $\mu(\mathrm{I})-\mu(\mathrm{J})$ & SD & Sig \\
\hline$P B L$ & $D I$ & $21.229^{*}$ & 2.694 & 0.000 \\
$D I$ & $P B L$ & $-21.229^{*}$ & 2.694 & 0.000 \\
\hline
\end{tabular}

Tabel 9:

Signifikansi Perbedaan Skor Rata-rata Prestasi Belajar antara Kelompok Motivasi Berprestasi Tinggi dan Motivasi Berprestasi Rendah

\begin{tabular}{ccccc}
\hline (I) Motivasi & $(J)$ Motivasi & $\mu(\mathrm{I})-\mu(\mathrm{J})$ & SD & Sig \\
\hline MBT & MBT & $7.246^{*}$ & 2.828 & 0.012 \\
MBR & MBR & $-7.246^{*}$ & 2.828 & 0.012 \\
\hline
\end{tabular}

(Problem Based Learning atau Pembelajaran Berbasis Masalah) dengan model DI (Direct Instruction atau Pembelajaran Langsung) adalah $\Delta \mu=\mu(\mathrm{I})-\mu(\mathrm{J})=21.229$, dengan standar deviasi 2.694, dan angka signifikansi 0.0001 . Angka signifikansi lebih kecil dari pada 0.05 , sedangkan nilai $\Delta \mu$ lebih besar daripada nilai LSD atau Least Significant Difference (Hayter, 1986; Abdi et al., 2009; dan Williams \& Abdi, 2010). Berdasarkan perhitungan diperoleh nilai LSD adalah 5.2143 .

Ini berarti terdapat perbedaan skor ratarata prestasi belajar yang signifikan antara kelompok model PBL dan kelompok model DI. Prestasi belajar yang dicapai oleh siswa yang belajar dengan model pembelajaran PBL lebih tinggi dibandingkan dengan siswa yang belajar dengan model DI ( $c f$ Kusuma, Dibia \& Suwatra, 2014; Wasonowati, 2014; dan Adriadi \& Tarihoran, 2016).

Berdasarkan sumber pengaruh motivasi berprestasi diperoleh nilai $\mathrm{F}_{\text {hitung }}\left(\mathrm{F}_{\text {MOTIVASI }}{ }^{*}\right)$ $=6.566$, dengan angka signifikansi 0.012 . Oleh karena angka signifikasinya lebih kecil dari 0.05 , maka diputuskan $\mathrm{H}_{0}$ ditolak dan $\mathrm{H}_{\mathrm{A}}$ diterima. Secara empiris terbukti kebenarannya bahwa terdapat perbedaan prestasi belajar Fisika antar siswa dengan MBT (Motivasi Berprestasi Tinggi) dan siswa dengan MBR (Motivasi Berprestasi Rendah). Signifikansi perbedaan skor ratarata prestasi belajar antara kelompok siswa MBT dan kelompok siswa MBR dianalisis menggunakan LSD (Hayter, 1986; Abdi et al., 2009; dan Williams \& Abdi, 2010).

Rangkuman hasil pengujian signifikansi perbedaan skor rata-rata prestasi belajar antara MBT dan MBR disajikan pada tabel 9.

Berdasarkan tabel 9, perbedaan skor rata- 
Tabel 10:

Hasil Post Hoc Tukey HSD

\begin{tabular}{clccccc}
\hline $\begin{array}{c}\text { (I) } \\
\text { Kelompok }\end{array}$ & $\begin{array}{c}(\boldsymbol{J}) \\
\text { Kelompok }\end{array}$ & $\begin{array}{c}\text { Mean } \\
\text { Difference (I-J) }\end{array}$ & $\begin{array}{c}\text { Std. } \\
\text { Error }\end{array}$ & Sig. & \multicolumn{2}{c}{ 95\% Confidence Interval } \\
\hline \multirow{3}{*}{ PBL \& MBT } & PBL\&MBR & $19.00000^{*}$ & 4.00240 & 0.000 & 8.5089 & 29.4911 \\
& DI \& MBT & $29.95455^{*}$ & 4.00240 & 0.000 & 19.4634 & 40.4457 \\
& DI \& MBR & $30.86364^{*}$ & 4.00240 & 0.000 & 20.3725 & 41.3548 \\
\hline \multirow{3}{*}{ PBL \& MBR } & PBL\&MBT & $-19.00000^{*}$ & 4.00240 & 0.000 & -29.4911 & -8.5089 \\
& DI \& MBT & $10.95455^{*}$ & 4.00240 & 0.037 & 0.4634 & 21.4457 \\
& DI \& MBR & $11.86364^{*}$ & 4.00240 & 0.020 & 1.3725 & 22.3548 \\
\hline \multirow{2}{*}{ DI \& MBT } & PBL\&MBT & $-29.95455^{*}$ & 4.00240 & 0.000 & -40.4457 & -19.4634 \\
& PBL\&MBR & $-10.95455^{*}$ & 4.00240 & 0.037 & -21.4457 & -0.4634 \\
& DI\&MBR & 0.90909 & 4.00240 & 0.996 & -9.5820 & 11.4002 \\
\hline \multirow{2}{*}{ DI \& MBR } & PBL\&MBT & $-30.86364^{*}$ & 4.00240 & 0.000 & -41.3548 & -20.3725 \\
& PBL\&MBR & $-11.86364^{*}$ & 4.00240 & 0.020 & -22.3548 & -1.3725 \\
& DI\&MBT & -0.90909 & 4.00240 & 0.996 & -11.4002 & 9.5820
\end{tabular}

rata prestasi belajar siswa antara kelompok siswa MBT (Motivasi Berprestasi Tinggi) dengan kelompok siswa MBR (Motivasi Berprestasi Rendah) adalah $\Delta \mu=\mu(\mathrm{I})-\mu(\mathrm{J})$ $=7.246$, dengan standar deviasi 2.828, dan angka signifikansi 0.012. Angka signifikansi lebih kecil daripada 0.05 , sedangkan nilai $\Delta \mu$ lebih besar dari pada nilai LSD atau Least Significant Difference (Hayter, 1986; Abdi et al., 2009; dan Williams \& Abdi, 2010), dimana berdasarkan perhitungan diperoleh nilai LSD adalah 5.2143. Ini berarti terdapat perbedaan skor rata-rata prestasi belajar yang signifikan antara kelompok siswa MBT dan kelompok siswa MBR. Prestasi belajar yang dicapai oleh siswa yang belajar dengan MBT lebih tinggi dibandingkan dengan siswa yang belajar dengan MBR ( $c f$ Nurhidayah, 2015; Idris, 2016; dan Sutama, Wahyudiyanto \& Narimo, 2017).

Dari hasil ANAKOVA (Analisis Kovarian) dua jalur didapat $\mathrm{FAB}_{\text {hitung }}{ }^{*}=$ 10.420 , dengan angka signifikansi 0.002 . Oleh karena angka signifikasinya lebih kecil dari 0.05 , sehingga diputuskan $\mathrm{H}_{0}$ ditolak dan $\mathrm{H}_{\mathrm{A}}$ diterima. Hipotesis penelitian yang menyatakan bahwa terdapat pengaruh interaktif antara model pembelajaran dengan motivasi berprestasi terhadap prestasi belajar Fisika siswa, secara empiris terbukti kebenarannya, setelah perlakuan dikontrol dengan kovariabel prestasi belajar awal ( $c f$ Ruslindawati, 2012; Widowati, Susanto \& Yulianto, 2013; dan Mustofa, 2014).

Selanjutnya, untuk mengetahui pengaruh interaksi antara model pembelajaran dan motivasi berprestasi terhadap prestasi belajar, dilanjutkan dengan uji model John Tukey (cf Tukey, 1949; Nainggolan, 2009; and Montgomery, 2013). Rangkuman uji dengan model John Tukey (1949) disajikan pada tabel 10.

Berdasarkan tabel 10 dapat dilihat untuk uji model John Tukey (1949) tampak bahwa pada sel 3 dan 4, tepatnya antara siswa yang belajar menggunakan model DI (Direct Instruction atau Pembelajaran Langsung) untuk siswa yang mempunyai MBT (Motivasi Berprestasi Tinggi) dan MBR (Motivasi Berprestasi Rendah) tidak terdapat perbedaan secara signifikan dengan angka signifikansi 0.996 lebih besar dibandingkan dengan nilai taraf signifikansi 0.05 dan perbedaan rata-rata kelompok 0.90909 lebih kecil dengan nilai HSD (Honestly Significant Difference), yaitu 10.4941 ( $c f$ Tukey, 1949; Hayter, 1986; Abdi et al., 2009; Nainggolan, 2009; Williams \& Abdi, 2010; dan Montgomery, 2013).

Perbedaan yang signifikan terjadi antara siswa yang belajar menggunakan model 
PBL (Problem Based Learning atau Pembelajaran Berbasis Masalah) untuk siswa yang mempunyai MBT dengan siswa yang mempunyai MBR, dengan angka signifikansi 0.0001 lebih kecil dibandingkan dengan nilai taraf signifikansi 0.05 dan perbedaan rata-rata kelompok 19.000 lebih besar dengan nilai HSD, yaitu 10,4941. Begitu pula antara siswa yang belajar menggunakan model PBL dengan siswa yang belajar menggunakan model DI untuk siswa yang mempunyai MBT terdapat perbedaan yang signifikan dengan angka signifikansi 0.0001 lebih kecil dibandingkan dengan nilai taraf signifikansi 0.05 dan perbedaan rata-rata kelompok 29.95455 lebih besar dengan nilai HSD yaitu 10.4941 .

Perbedaan yang signifikan juga terjadi antara siswa yang belajar menggunakan model PBL untuk siswa yang mempunyai MBT dengan siswa yang belajar model DI untuk siswa yang mempunyai MBR dengan angka signifikansi 0.0001 lebih kecil dibandingkan dengan nilai taraf signifikansi 0.05 , dan perbedaan rata-rata kelompok 30.86364 lebih besar dengan nilai HSD, yaitu 10.4941 .

Perbedaan yang signifikan terjadi antara siswa yang belajar menggunakan model PBL untuk siswa yang mempunyai MBR dengan siswa yang belajar menggunakan model DI untuk siswa yang mempunyai MBT dengan angka signifikansi 0.037 lebih kecil dibandingkan dengan nilai taraf signifikansi 0.05 dan perbedaan rata-rata kelompok 10.95455 lebih besar dengan nilai HSD, yaitu 10.4941. Begitu pula antara siswa yang belajar menggunakan model PBL untuk siswa yang mempunyai MBT dengan siswa yang belajar menggunakan model DI untuk siswa yang mempunyai MBR terdapat perbedaan yang signifikan dengan angka signifikansi 0.020 lebih kecil dibandingkan dengan nilai taraf signifikansi

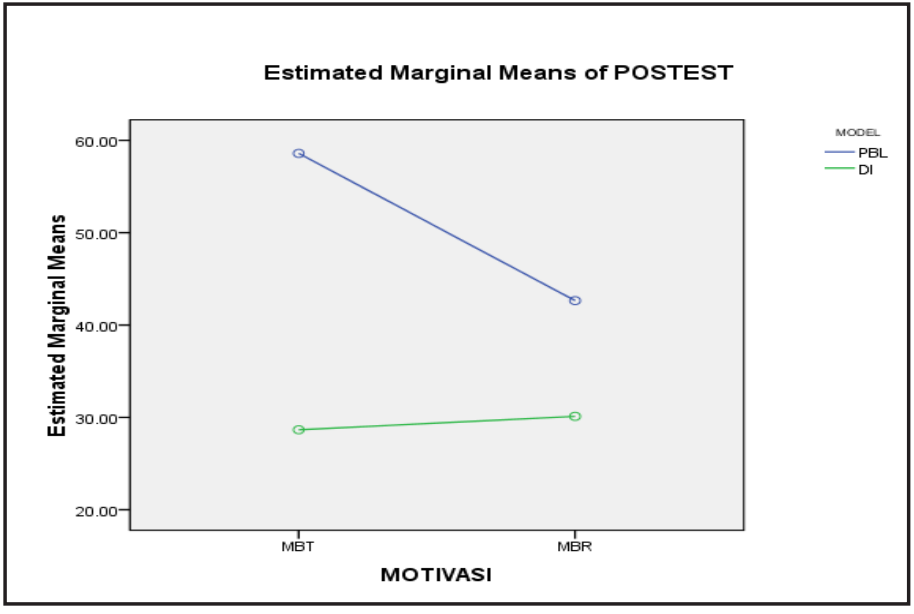

Gambar 3:

Profil Interaksi antara Model Pembelajaran dan Motivasi Berprestasi

0.05 , dan perbedaan rata-rata kelompok 11.86364 lebih besar dengan nilai HSD, yaitu 10.4941 .

Hasil uji John Tukey (1949) ini menunjukan bahwa terdapat pengaruh interaktif antara model pembelajaran dan motivasi berprestasi terhadap prestasi belajar Fisika siswa. Hasil uji John Tukey (1949) juga menunjukan bahwa baik siswa yang mempunyai MBT dan siswa yang mempunyai MBR yang belajar menggunakan model PBL memperoleh nilai yang lebih tinggi dibanding dengan siswa yang belajar menggunakan model DI ( $c f$ Tukey, 1949; Nafiah, 2014; dan Hizbi \& Wajdi, 2017).

Berdasarkan hasil statistik rerata dengan bantuan program SPSS (Statistical Package for the Social Sciences) 23.0 for windows untuk prestasi belajar Fisika diperoleh profil interaksi antara model pembelajaran dengan motivasi berprestasi, yang ditunjukkan pada gambar 3.

Berdasarkan gambar 3 menunjukan interaksi antar motivasi berprestasi dari siswa, yakni MBT (Motivasi Berprestasi Tinggi) dan MBR (Motivasi Berprestasi Rendah), dipengaruhi oleh model pembelajaran yang digunakan, yakni PBL (Problem Based Learning atau Pembelajaran 
Berbasis Masalah) dan DI (Direct

Learning atau Pembelajaran Langsung) dalam pencapaian prestasi belajar Fisika (Sugiyanto, 2007; Nurhidayah, 2015; dan Sutama, Wahyudiyanto \& Narimo, 2017).

Pembahasan. Dalam pembahasan ini dikaji dan dianalisis tiga hal, yakni: (1) Pengaruh Model Pembelajaran "Problem Based Learning" dan Model "Direct Learning" terhadap Prestasi Belajar; (2) Pengaruh Motivasi Berprestasi terhadap Prestasi Belajar Fisika Siswa; dan (3) Pengaruh Interaksi antara Model Pembelajaran dengan Motivasi Berprestasi terhadap Prestasi Belajar Fisika. Masingmasing penjelasannya adalah sebagai berikut:

Pertama, Pengaruh Model Pembelajaran "Problem Based Learning” dan Model "Direct Learning” terhadap Prestasi Belajar. Pengaruh penerapan model pembelajaran terhadap prestasi belajar Fisika telah dilakukan analisis data dengan menggunakan ANAKOVA (Analisis Kovarian) dua jalur. Berdasarkan hasil analisis diperoleh harga $\mathrm{F}_{\text {(Hitung) }}{ }^{*}$ sebesar 62.082, dengan angka signifikansi 0.0001 . Angka signifikansi lebih kecil dari 0.05, ini berarti Ho ditolak dan $\mathrm{H}_{\mathrm{A}}$ diterima. Jadi, terdapat perbedaan prestasi belajar Fisika yang signifikan antara kelompok siswa yang mengikuti model PBL (Problem Based Learning atau Pembelajaran Berbasis Masalah) dengan kelompok siswa yang mengikuti model DI (Direct Instruction atau Pembelajaran Langsung).

Jika kita perhatikan rerata prestasi belajar Fisika antara kedua kelompok, dimana rerata prestasi belajar Fisika pada kelompok siswa yang belajar menggunakan model PBL sebesar 59.9545; dan pada kelompok siswa yang belajar menggunakan model DI sebesar 30.000. Prestasi belajar Fisika pada kelompok siswa yang belajar menggunakan model PBL lebih tinggi dibandingkan dengan kelompok siswa yang belajar menggunakan model DI (Akinoglu
\& Ruhan, 2007; Selcuk, 2013; dan Aidoo, Boateng \& Ofori, 2016).

Berdasarkan uji lanjut LSD atau Least Significant Difference (Hayter, 1986; Abdi et al., 2009; dan Williams \& Abdi, 2010), nilai $\Delta \mu$ lebih besar daripada nilai LSD, dimana berdasarkan perhitungan diperoleh nilai LSD adalah 5.2143. Ini berarti bahwa terdapat perbedaan skor rata-rata prestasi belajar yang signifikan antara kelompok PBL dan kelompok DI. Prestasi belajar yang dicapai oleh siswa yang belajar dengan model pembelajaran PBL lebih tinggi dibandingkan dengan siswa yang belajar dengan model DI (cf Wardhani, 2012; Selcuk, 2013; dan Aidoo, Boateng \& Ofori, 2016).

Hal ini sejalan dengan penelitian yang dilakukan oleh M.M. Melissa (2016), dan sarjana lainnya, bahwa pendekatan PBL mampu meningkatkan prestasi belajar siswa (Selcuk, 2013; Aidoo, Boateng \& Ofori, 2016; dan Melissa, 2016). Hal senada juga disampaikan oleh S.K. Alpat \& T. Gunter (2016), dan sarjana lainnya, bahwa model pembelajaran PBL lebih efektif dalam meningkatkan prestasi belajar dibandingkan dengan model pembelajaran ekspositori (Alpat \& Gunter, 2016; Acep, 2018; dan Raharjo, Khairudin \& Baser, 2018).

Ada perbedaan pengaruh antara model pembelajaran PBL dengan model pembelajaran DI dalam pembelajaran Fisika, dalam hal peningkatan prestasi belajar. Dalam pembelajaran Fisika, model pembelajaran PBL terbukti lebih baik dibandingkan dengan model pembelajaran DI ( $c f$ Wardhani, 2012; Selcuk, 2013; dan Rengganis, Dwijananti \& Sarwi, 2015).

Berpijak pada kenyataan tersebut, model PBL merupakan salah satu model pembelajaran yang inovatif, dimana siswa ditempatkan sebagai subjek belajar, sehingga pembelajaran lebih berpusat pada siswa. Model PBL dirancang untuk membantu peserta didik mengembangkan keterampilan berpikir, keterampilan menyelesaikan masalah, dan keterampilan 
intelektualnya. Model PBL juga

memfasilitasi peserta didik, melalui kegiatan investigasi dan diskusi, untuk menentukan dan memutuskan penyelesaian mana yang dianggap paling baik (Selcuk, 2013; Alpat \& Gunter, 2016; dan Melissa, 2016).

Berbeda dengan pembelajaran PBL, penyelenggaraan pembelajaran DI cenderung menekankan kepada tujuan pembelajaran berupa penambahan pengetahuan, dan siswa dituntut untuk dapat mengungkapkan kembali pengetahuan yang sudah dipelajari melalui kuis atau tes terstandar. Model pembelajaran DI menekankan hasil agar suatu informasi dari guru dapat tersampaikan pada siswa, baik melalui instruksi langsung, ceramah, ataupun pemberian tugas latihan-latihan soal, tanpa harus memperhatikan kaitan sebuah konsep serta pengetahuan dengan kehidupan nyata siswa itu sendiri. Kegiatan pembelajaran yang benar-benar formal, seperti model DI, tentu kurang efektif dalam mengembangkan prestasi belajar siswa ( $c f$ Wenno, 2014; Rengganis, Dwijananti \& Sarwi, 2015; Sidik \& Winata, 2016; Bahri, Putriana \& Idris, 2018; dan Irawan, 2018).

Pada kegiatan pembelajaran di kelompok kontrol, siswa diberikan permasalahan Fisika dan siswa diarahkan untuk mendiskusikan bagaimana penyelesaiannya. Pada proses pembelajarannya, saat diskusi kelompok terkadang diskusinya memerlukan waktu yang lebih lama. Melihat kondisi tersebut, tanpa disadari, guru cenderung memberikan bantuan secara langsung kepada siswa. Hal itu membuat siswa tidak terbiasa mencari penyelesaian dengan cara mereka sendiri. Penerapan model pembelajaran DI, juga kurang memberikan kesempatan kepada siswa untuk merefleksikan setiap proses pembelajaran. Kegiatan refleksi sangat penting dikembangkan agar siswa mampu melihat kekurangannya, sebagai langkah untuk meningkatkan kualitas pembelajaran (Ewing, 2011; Wenno, 2014; dan Yankie, 2018).
Kedua, Pengaruh Motivasi Berprestasi terhadap Prestasi Belajar Fisika Siswa. Berdasarkan hasil uji hipotesis yang telah dilakukan terhadap data yang diperoleh dari hasil penelitian, maka ditemukan bahwa terdapat perbedaan prestasi belajar siswa yang dicapai oleh kelompok siswa yang memiliki MBT (Motivasi Berprestasi Tinggi) dengan siswa yang memiliki MBR (Motivasi Berprestasi Rendah). Dalam penelitian ini ditemukan bahwa, secara deskriptif, prestasi belajar Fisika kelompok siswa yang memiliki MBT lebih tinggi dibandingkan dengan kelompok siswa yang memiliki MBR ( $c f$ Gunadi \& Gunawan, 2014; Afiati, 2015; dan Sutama, Wahyudiyanto \& Narimo, 2017). Hal ini dapat terlihat dari skor rata-rata prestasi belajar Fisika pada siswa yang memiliki MBT, yakni 41.8182; sedangkan pada siswa yang memiliki MBR sebesar 35.0227.

Hasil analisis menunjukan bahwa skor statistik $\mathrm{F}$ diperoleh dari sumber pengaruh motivasi berprestasi belajar $\mathrm{F}^{*}=6.566$ dengan angka signifikansi 0.012 . Oleh karena angka signifikasinya lebih kecil dari 0.05 , maka ianya memiliki makna bahwa terdapat perbedaan prestasi belajar yang dicapai siswa oleh kelompok yang memiliki MBT dengan siswa yang memiliki MBR. Berdasarkan uji lanjut LSD atau Least Significant Difference (Hayter, 1986; Abdi et al., 2009; dan Williams \& Abdi, 2010), nilai $\Delta \mu$ lebih besar dari pada nilai LSD, dimana berdasarkan perhitungan diperoleh nilai LSD adalah 5.2143. Ini berarti bahwa terdapat perbedaan skor rata-rata prestasi belajar yang signifikan antara kelompok siswa MBT dan kelompok siswa MBR (Gunadi \& Gunawan, 2014; Afiati, 2015; dan Sutama, Wahyudiyanto \& Narimo, 2017).

Prestasi belajar yang dicapai oleh siswa yang belajar dengan MBT lebih tinggi dibandingkan dengan siswa yang belajar dengan MBR. Ini menunjukan bahwa prestasi belajar siswa yang dicapai oleh kelompok siswa yang mengikuti 
pembelajaran dengan MBT relatif lebih baik dibandingkan dengan kelompok siswa yang mengikuti pembelajaran dengan MBR. Hal ini sejalan dengan penelitian oleh Z. Akbari, H.M. Mahmouei \& M. Pakdaman (2015), dan sarjana lainnya, yang menyatakan bahwa ada korelasi positif antara motivasi berprestasi dengan prestasi belajar. Prestasi belajar yang baik akan dimiliki oleh siswa yang memiliki MBT. Prestasi belajar Fisika yang mempunyai MBT bila dibandingkan dengan prestasi belajar Fisika yang mempunyai MBR, pasti akan berbeda secara signifikan (Saefullah, Siahaan \& Sari, 2013; Akbari, Mahmouei \& Pakdaman, 2015; dan Idris, 2016).

Hasil kajian ini dijelaskan oleh penelitian-penelitian sebelumnya, antara lain, oleh Arvyati, F. Maonde \& N. Noho (2016) dan sarjana-sarjana lainnya, yang menyatakan bahwa motivasi beprestasi sangat berperan penting dalam belajar. Dengan motivasi inilah siswa menjadi tekun dalam belajar, dan dengan motivasi pula kualitas prestasi belajar siswa kemungkinan dapat diwujudkan dengan baik. Siswa yang dalam proses belajar mengajar mempunyai motivasi berprestasi yang kuat dan tekun, kemungkinan besar memperoleh prestasi belajar yang memuaskan (Mukhtar, 2015; Arvyati, Maonde \& Noho, 2016; dan Saptono, 2016).

Hal itu disebabkan oleh adanya ketiga fungsi motivasi, sebagai berikut: (1) mendorong manusia untuk berbuat, jadi sebagai penggerak atau motor yang melepaskan energi, dimana motivasi dalam hal ini merupakan motor penggerak dalam setiap kegiatan yang akan dikerjakan; (2) menentukan arah perbuatan, yakni kearah tujuan yang hendak dicapai, yang dengan demikian motivasi dapat memberikan arah dan kegiatan yang harus dikerjakan sesuai dengan rumusan tujuannya; serta (3) menyeleksi perbuatan, yakni menentukan perbuatan-perbuatan apa yang hendak dikerjakan, yang serasi guna mencapai tujuan, dengan menyisihkan perbuatanperbuatan yang tidak bermanfaat bagi tujuan tersebut (Sardiman, 2006; Emda, 2017; dan Nas, 2017).

Siswa yang mempunyai motivasi berprestasi yang baik ditandai dengan beberapa hal, antara lain, siswa tersebut berusaha unggul dalam bersaing; menyelesaikan tugas dengan baik; rasional dalam meraih keberhasilan; suka dengan tantangan; menerima tanggung jawab untuk kepentingan sosial; serta menyukai situasi pekerjaan untuk tanggung jawab pribadi, umpan balik, dan resiko tingkat menengah (cf Mulyani, 2006; Arvyati, Maonde \& Noho, 2016; dan Nas, 2017).

Ketiga, Pengaruh Interaksi antara Model Pembelajaran dengan Motivasi Berprestasi terhadap Prestasi Belajar Fisika. Hasil analisis dengan ANAKOVA (Analisis Kovarian) dua jalur, seperti yang tertera pada tabel-tabel sebelumnya, diperoleh $\mathrm{F}_{\mathrm{AB}(\mathrm{Hitung})}{ }^{*}=11.709$, dengan angka signifikansi 0.002. Angka signifikasinya lebih kecil dari 0.05, maka ini berarti bahwa Ho ditolak dan $\mathrm{H}_{\mathrm{A}}$ diterima. Kesimpulannya adalah terdapat interaksi antara model pembelajaran dan motivasi berprestasi siswa terhadap prestasi belajar Fisika. Temuan ini juga sesuai dengan hasil penelitian yang dilakukan oleh M. Ispriyanto \& S. Mulyani (2014), dan sarjana lainnya, yang menyatakan bahwa terdapat pengaruh interaksi antara model pembelajaran dengan motivasi berprestasi terhadap prestasi belajar (Ispriyanto \& Mulyani, 2014; Herlina, Kasim \& Mamu, 2016; dan Hizbi \& Wajdi, 2017).

Interaksi yang terjadi antara model pembelajaran dan motivasi berprestasi terhadap prestasi belajar Fisika siswa dalam penelitian ini menunjukan bahwa model PBL (Problem Based Learning atau Pembelajaran Berbasis Masalah) lebih unggul, baik pada siswa yang mempunyai MBT (Motivasi Berprestasi Tinggi) maupun siswa yang mempunyai MBR 
(Motivasi Berprestasi Rendah). Ini berarti bahwa model PBL memiliki lebih banyak keunggulan dibandingkan dengan model DI (Direct Instruction atau Pembelajaran Langsung). Hal ini dibuktikan dengan siswa yang mempunyai MBT, skor ratarata prestasi belajar Fisika yang mengikuti pembelajaran dengan model PBL mencapai 59.9545; sedangkan skor rata-rata yang mengikuti model DI mencapai 30.000. Skor rata-rata prestasi belajar Fisika siswa yang mempunyai MBR, yang mengikuti pembelajaran dengan model PBL mencapai 40.9545; sedangkan skor rata-rata yang mengikuti model DI mencapai 29.0909. Sehingga, secara keseluruhan, prestasi belajar siswa dengan model PBL lebih tinggi bila dibandingkan dengan prestasi belajar siswa yang belajar menggunakan model DI (Ahmed, 2007; Sidik \& Winata, 2016; Kizkapan \& Bektas, 2017; dan Satrianingsih, Haryani \& Dewi, 2017).

Model PBL memberikan pertanyaanpertanyaan yang bersifat membangun motivasi dan rasa ingin tahu siswa terhadap masalah yang diberikan, sehingga pembelajaran lebih kondusif. Siswa yang memiliki MBT, yang dibelajarkan menggunakan model PBL, akan lebih bersemangat dalam belajar dan lebih berani mengemukakan pendapat ataupun pertanyaan. Siswa yang memiliki MBT juga sangat menyukai pelajaran Fisika dengan aktivitas yang berkaitan dengan praktek. Berbeda dengan siswa yang memiliki MBR akan cepat putus asa ketika tidak mampu menyelesaikan masalah yang diberikan pada LKS (Lembar Kerja Siswa). Guru sering memberikan motivasi dan pertanyaan yang menuntun siswa dalam membangun pengetahuannya dan membuat siswa yang memiliki MBR lebih bertahan dan sabar dalam mengerjakan LKS, karena membuat mereka tahu langkah-langkah apa yang harus mereka lakukan (Aidoo, Boateng \& Ofori, 2016; Achmad et al., 2017; dan Sutama, Wahyudiyanto \& Narimo, 2017).
Model DI kurang memberikan kesempatan kepada siswa untuk membangun pengetahuannya. Pembelajaran pada model DI masih didominasi oleh guru, sehingga siswa terkadang kurang bersemangat untuk mengikuti pembelajaran. Siswa yang memiliki MBT, yang dibelajarkan dengan model DI, akan merasa malas untuk belajar karena tidak diberikan kesempatan untuk dirinya dalam memberikan pendapat terkait permasalahan yang diberikan oleh guru. Guru sering memberikan pertanyaanpertanyaan kepada siswa, namun guru juga yang melakukan penyelesaian terkait pertanyaan yang diberikan. Berbeda dengan siswa yang memiliki motivasi rendah, mereka akan lebih senang apabila guru langsung memberikan penyelesaian, sehingga siswa lebih tahu cara menyelesaikan pertanyan-pertanyaan yang serupa. Pada model DI, siswa yang memiliki MBR memiliki skor prestasi belajar lebih tinggi dibandingkan dengan MBT (Aufan, 2011; Watanabe et al., 2013; Arvyati, Maonde \& Noho, 2016; dan Achmad et al., 2017).

Dari uraian di atas dapat dikatakan bahwa model PBL memberikan dampak positif dalam pembelajaran. Model PBL juga menciptakan suasana kondusif dalam pembelajaran. Hal ini dikarenakan siswa lebih aktif, lebih bertahan dalam tugastugas yang diberikan, tentunya hal ini akan mempengaruhi prestasi belajar Fisika siswa yang mereka peroleh. Siswa yang memiliki, baik MBT maupun MBR, yang dibelajarkan dengan model PBL akan memiliki prestasi belajar yang lebih baik, maka dapat dikatakan terdapat interaksi antara model pembelajaran dan motivasi berprestasi terhadap prestasi belajar (Akinoglu \& Ruhan, 2007; Arvyati, Maonde \& Noho, 2016; Achmad et al., 2017; dan Satrianingsih, Haryani \& Dewi, 2017).

\section{KESIMPULAN}

Berdasarkan data yang telah dikumpulkan dan hasil analisis data yang 
telah dikemukakan, maka dapat disimpulkan bahwa terdapat perbedaan yang signifikan pada prestasi belajar Fisika antara siswa yang belajar dengan model PBL (Problem Based Learning atau Pembelajaran Berbasis Masalah) dan siswa yang belajar dengan model DI (Direct Instruction atau Pembelajaran Langsung) pada siswa Kelas X SMAN (Sekolah Menengah Atas Negeri) 1 Kubutambahan di Bali, Indonesia, dimana siswa yang belajar dengan model PBL, prestasi belajar Fisika lebih tinggi dibandingkan siswa yang belajar model pembelajaran DI.

Terdapat perbedaan yang signifikan pada prestasi belajar Fisika antara siswa yang mempunyai MBT (Motivasi Berprestasi Tinggi) dengan siswa yang mempunyai MBR (Motivasi Berprestasi Rendah). Prestasi belajar siswa yang mempunyai MBT lebih tinggi dibandingkan dengan siswa yang mempunya MBR. Terdapat juga pengaruh interaktif antara model pembelajaran dengan motivasi berprestasi. Kedua model pembelajaran cenderung berinteraksi secara kuat dengan MBT. Berdasarkan temuan di atas dapat disimpulkan bahwa penerapan model PBL dan motivasi berprestasi berpengaruh terhadap prestasi belajar Fisika.

Rekomendasi dari hasil penelitian ini adalah dapat dikembangkan dengan penelitian yang serupa, yaitu penelitian tentang faktor internal lain seperti kreativitas, prokratinasi, gaya belajar, sikap ilmiah, dan lain-lain, yang mempengaruhi prestasi belajar siswa agar semakin luas pemahaman faktor internal yang mempengaruhi prestasi belajar. Guru juga diharapkan memperhatikan karakteristik siswa dalam menerapkan model PBL, yang akan diterapkan selama proses pembelajaran demi pencapaian prestasi belajar yang optimal. $^{1}$

${ }^{1}$ Pernyataan: Kami, dengan ini, menyatakan bahwa artikel ini, beserta seluruh isinya, adalah benar-benar karya kami sendiri, dan kami tidak melakukan penjiplakan atau

\section{Referensi}

Abdi, H. et al. (2009). Experimental Design and Analysis for Psychology. Oxford: Oxford University Press.

Acep. (2018). "Perbandingan Model Pembelajaran PBL dan Ekspositori terhadap Hasil Belajar PKN" dalam FAKTOR: Jurnal Ilmiah Kependidikan, Vol.5, No.1 [Maret], hlm.71-82. Tersedia secara online juga di: http://digilib. mercubuana.ac.id/manager/t!@,file artikel abstrak/Isi_Artikel_131787308622.pdf [diakses di Singaraja, Bali, Indonesia: 15 Januari 2019].

Achmad, R.I. et al. (2017). "Hubungan antara Motivasi Berprestasi dan Kebiasaan Belajar terhadap Prestasi Belajar Fisika" dalam Prosiding Seminar Nasional, Volume 3(1), hlm.177-187. Tersedia secara online juga di: https://www. researchgate.net/publication /323498151 [diakses di Singaraja, Bali, Indonesia: 22 November 2018].

Adriadi, Ade \& Naf'an Tarihoran. (2016). "Pembelajaran Problem Based Learning (PBL) dan Motivasi Siswa terhadap Hasil Belajar PAI di SMP Negeri I Ciruas - Serang" dalam Saintifika Islamica: Jurnal Kajian Keislaman, Vol.3, No.2 [Juli - Desember], hlm.15-38.

Afiati, Tyas Fahmi. (2015). "Pengaruh Motivasi Berprestasi dan Kontinuitas Belajar terhadap Prestasi Belajar Otomatisasi Perkantoran Siswa Kelas X Kompetensi Keahlian Administrasi Perkantoran SMK Negeri 1 Purbalingga Tahun Ajaran 2014/2015". Skripsi Sarjana Tidak Diterbitkan. Yogyakarta: Jurusan Pendidikan Administrasi FE UNY [Fakultas Ekonomi, Universitas Negeri Yogyakarta]. Tersedia secara online juga di: https://eprints.uny.ac.id/25542/1/ Skripsi\%20Full-Tyas\%20Fahmi\%20 Afiati-11402241008.pdf [diakses di Singaraja, Bali, Indonesia: 15 Januari 2019].

Ahmed, A. (2007). "Direct Instruction and Appropriate Invention for Children with Learning Problem" in The Turkish Online Journal of Educational Technology, Volume 6, Issue 2, pp.23-25.

Aidoo, B., S.K. Boateng \& I. Ofori. (2016). "Effect of Problem-Based Learning on Students Achievement in Chemistry" in Journal of Eduation and Practice, Vol.7, No.33.

pengutipan dengan cara yang tidak sesuai dengan etika keilmuan yang berlaku dalam masyarakat akademik. Atas pernyataan ini, kami siap menanggung resiko atau sanksi yang dijatuhkan kepada kami, apabila kemudian ditemukan adanya pelanggaran terhadap etika keilmuan dalam karya kami, atau ada klaim dari pihak lain terhadap keaslian karya kami ini. 
Akbari, Z., H.M. Mahmouei \& M. Pakdaman. (2015). "Review of the Relationship between Self-Efficacy of Teachers with Achievement Motivation and Academic Achievement" in Journal of Social Issues \& Humanities, Volume 3(1), pp.278-284. Available online also at: http:// www.journalsih.com [accessed in Singaraja, Bali, Indonesia: 7 November 2018].

Akinoglu, O. \& O. Ruhan. (2007). "The Effect of Problem Based Active Learning in Science Education on Student's Academic Achievement, Attitude, and Concept Learning" in Eurasia Journal of Mathematics, Science \& Technology Education, Vol.3, No.1.

Alpat, S.K. \& T. Gunter. (2016). "The Effects of Problem Based Learning (PBL) on the Academic Achievement of Students Studying 'Electrochemistry"' in Chemistry Education Research and Practice, DOI: 10.1039/ C6RP00176A. Available online also at: $\underline{\mathrm{http}: / /}$ pubs.rsc.org/en/content/articlelading/2017/ rp/c6rp00176a [accessed in Singaraja, Bali, Indonesia: 7 November 2018].

Anazifa, R.D. (2016). "The Effect of ProblemBased Learning on Critical Thinking and Student Achievement in the Bantul Senior High School". Paper for an International Conference on Educational Research and Innovation. Available online also at: www.eprints.uny.ac.id/41337/ [accessed in Singaraja, Bali, Indonesia: 7 November 2018].

Angell, C., O. Guttersurd \& E.K. Henriksen. (2007). Multiple Representations as a Framework for a Modelling Approach to Physics Education. Norway and UK [United Kingdom: Department of Physics, University of Oslo and Per Morten Kind, School of Education, Durham University.

Arvyati, F. Maonde \& N. Noho. (2016). "Pengaruh Motivasi Berprestasi terhadap Prestasi Belajar Matematika Siswa SMA Negeri dan SMA Swasta di Kota Kendari" dalam Jurnal Pendidikan Matematika, Volume 7(1), hlm.26-42. Tersedia secara online juga di: http://ojs.uho.ac.id/index. $\mathrm{php} / \mathrm{JPM} /$ article/view/2076/pdf [diakses di Singaraja, Bali, Indonesia: 21 November 2018].

Aufan, A.M.A. (2011). "The Effect of Direct Instruction Strategy on Math Achievement" in International Journal of Education Studies, Vol.4, No.4, pp.199-205.

Bahri, Arsad, Devi Putriana \& Irma Suryani Idris. (2018). "Peran PBL dalam Meningkatkan Keterampilan Pemecahan Masalah Biologi” dalam Jurnal Sainsmat, Vol.VII, No.2 [September], hlm.114-124.

Basuki, Agus Tri. (2015). Analisis Statistik dengan SPSS. Yogyakarta: Danisa Media. Tersedia secara online juga di: https://ekonometrikblog.files. wordpress.com/2018/12/STATISTIK-DENGANSPSS.pdf [diakses di Singaraja, Bali, Indonesia: 19 Desember 2018].

Cohen, M.L. (2008). "Fifty Years of Condensed Matter Physics" in Physical Review Letters, Volume 101(5), pp.25001-25006.

Cook, Thomas D. \& Donald T. Campbell. (1979). Quasi-Experimentation: Design \& Analysis Issues for Field Settings. Boston: Houghton Mifflin Company.

Desnylasari, E., S. Mulyani \& B. Mulyani. (2016). "Pengaruh Model Pembelajaran Project Based Learning dan Problem Based Learning pada Materi Termokimia terhadap Prestasi Belajar Siswa Kelas XI SMAN 1 Karanganyar, Tahun Pelajaran 2015/2016" dalam JPK: Jurnal Pendidikan Kimia, Volume 5(1), hlm.134-142. Tersedia secara online juga di: http://jurnal. fkip. uns.ac.id/index.php/kimia/article/view/74 $\underline{19}$ [diakses di Singaraja, Bali, Indonesia: 8 November 2018].

Dwi, I.M., H. Arif \& K. Sentot. (2013). "Pengaruh Strategi Problem Based Learning Berbasis ICT terhadap Pemahaman Konsep dan Kemampuan Pemecahan Masalah Fisika" dalam Jurnal Pendidikan Fisika Indonesia, Volume 9, hlm.8-17.

Emda, Amna. (2017). "Kedudukan Motivasi Belajar Siswa dalam Pembelajaran" dalam Lantanida Journal, Vol.5, No.2, hlm.93-196.

Etiubon, R.U. \& A.N. Ugwu. (2016). "ProblemBased Learning and Students' Academic Achievement on Thermodynamics: A Case Study of University of Uyo, Akwa-Ibom State, Nigeria" in IOSR Journal of Research \& Method in Education (IOSR-JRME), Volume 6(5), pp.3641. Available online also at: www.iosrjournals. org [accessed in Singaraja, Bali, Indonesia: 8 November 2017].

Ewing, B. (2011). "Direct Instruction in Mathematics, Issues for Schools with High Indigenous Enrolments: A Literature Review" in Australian Journal of Teacher Education, pp.65-92.

Gunadi, Chintia Leo \& William Gunawan. (2014). "Hubungan Motivasi Akademik dengan Prestasi Belajar Siswa SMA ' $X$ ' di Jakarta Barat” dalam Jurnal NOETIC Psychology, Vol.4, No.1 [JanuariJuni], hlm.23-42.

Hadi, R. (2007). "Dari Teacher Centered Learning ke Student Centered Learning: Perubahan Metode Pembelajaran di Perguruan Tinggi" dalam Insania, Vol.12, No.3, hlm.408-419.

Hayter, A.J. (1986). “The Maximum Familywise Error Rate of Fisher's Least Significant Difference Test" in Journal of the American Statistical Association, Volume 81, pp.1001-1004. 
Herlina, A. Kasim \& H.D. Mamu. (2016). "Pengaruh Model Problem Based Learning dan Motivasi Berprestasi terhadap Hasil Belajar Siswa pada Mata Pelajaran Biologi di Kelas XI IPA MAN 2 Model, Palu" dalam Jurnal Sains dan Teknologi Tadulako, Volume 5(1), hlm.11-18. Tersedia secara online juga di: http://jurnal.untad.ac.id/ jurnal/index.php/JSTT/article/download/6956 /5593 [diakses di Singaraja, Bali, Indonesia: 8 November 2017].

Hermawan, Edi. (2012). Pengantar Statistika NonParametrik. Bandung: Penerbit LPPM UNSIL [Lembaga Penelitian dan Pengabdian Masyarakat, Universitas Siliwangi].

Hidayat, Anwar. (2012). "Penelitian Eksperimen" dalam Statistikian. Tersedia secara online juga di: https://www.statistikian.com/2012/10/penelitianexperimen.html/amp [diakses di Singaraja, Bali, Indonesia: 19 Desember 2018].

Hidayat, Anwar. (2013). "Pengertian dan Rumus Uji Saphiro Wilk - Cara Hitung" dalam Statistikian. Tersedia secara online juga di: https://www. statistikian.com/2013/01/saphiro-wilk.html/ amp [diakses di Singaraja, Bali, Indonesia: 27 Desember 2018].

Hidayat, Anwar. (2017). "Perbedaan Uji Normalitas dan Homogenitas" dalam Statistikian. Tersedia secara online juga di: https://www.statistikian. com/2017/03/perbedaan-uji-normalitas-danhomogenitas.html/amp [diakses di Singaraja, Bali, Indonesia: 27 Desember 2018].

Hizbi, Tsamarul \& Badrul Wajdi. (2017). "Pengaruh Metode Pembelajaran dan Motivasi Berprestasi terhadap Hasil Belajar IPA-Fisika Siswa" dalam Kappa Journal, Vol.1, No.1. Tersedia secara online juga di: http://e-journal.hamzanwadi. ac.id/index.php/kpj/article/view/405 [diakses di Singaraja, Bali, Indonesia: 27 Desember 2018].

Idris, Muhammad. (2016). "Hubungan Motivasi Berprestasi dengan Prestasi Belajar Siswa pada Kelas XI SMA Nusantara Bandar Lampung Tahun Pelajaran 2015/2016”. Skripsi Sarjana Tidak Diterbitkan. Bandar Lampung: FKIP UNILA [Fakultas Keguruan dan Ilmu Pendidikan, Universitas Lampung]. Tersedia secara online juga di: http://digilib.unila.ac.id/22815/3/ SKRIPSI $\% 20$ TANPA $\% 20 B A B \% 20$ PEMBAHASAN.pdf [diakses di Singaraja, Bali, Indonesia: 27 Desember 2018].

Irawan, Muhamad Afriza. (2018). "Pengaruh Strategi Pembelajaran Aktif Tipe Giving Question and Getting Answers (GQGA) terhadap Pemecahan Masalah Matematika Peserta Didik Kelas V Madrasah Ibtidaiyah Negeri 6 Bandar Lampung”. Skripsi Sarjana Tidak Diterbitkan. Lampung: Fakultas Tarbiyah dan Keguruan UIN
[Universitas Islam Negeri] Raden Intan. Tersedia secara online juga di: http://repository.radenintan. ac.id/4030/1/SKRIPSI.pdf [diakses di Singaraja, Bali, Indonesia: 15 Januari 2019].

Ispriyanto, M. \& S. Mulyani. (2014). "Pembelajaran Kimia Menggunakan Model Guided Inquiry (MGI) dan Model Starter Experiment (MSE) Ditinjau dari Kreativitas dan Motivasi Berprestasi Siswa" dalam Jurnal Inkuiri, Volume 3(11), hlm.28-35. Tersedia secara online juga di: http:// jurnal.fkip.uns.ac.id/index.php/sains [diakses di Singaraja, Bali, Indonesia: 24 Januari 2019].

Kemendikbud RI [Kementerian Pendidikan dan Kebudayaan Republik Indonesia]. (2014). Lampiran Peraturan Menteri Pendidikan dan Kebudayaan RI Nomor 59 Tahun 2014 tentang Kurikulum 2013 Sekolah Menengah Atas/Madrasah Aliyah. Jakarta: Kementerian Pendidikan dan Kebudayaan Republik Indonesia.

Kizkapan, O. \& O. Bektas. (2017). "The Effect of Project Based Learning on Seventh Grade Students' Academic Achievement" in International Journal of Instruction, Volume 10(1). Available online also at: http://www. eiji.net/dosyalar/iji 2017 1 3.pdf [accessed in Singaraja, Bali, Indonesia: 5 Februari 2018].

Kurniawan, M. Arif, Agus Miftahillah \& Nilna Milhatan Nasihah. (2018). "Pembelajaran Berbasis Student-Centered Learning di Perguruan Tinggi: Suatu Tinjauan di UIN Sunan Kalijaga Yogyakarta" dalam Lentera Pendidikan, Vol.21, No.1 [Juni], hlm.1-11.

Kusuma, Nym Eriasa Adnyana, I Ketut Dibia \& Ign I Wayan Suwatra. (2014). "Pengaruh Model Pembelajaran Problem-Bassed Learning terhadap Hasil Belajar IPA pada Siswa Kelas V Semester Ganjil di Gugus XIV SD Kecamatan Buleleng, Kabupaten Buleleng, Tahun Pelajaran 2013/2014" dalam e-Journal MIMBAR PGSD Universitas Pendidikan Ganesha Jurusan PGSD, Vol.2, No.1.

Listiani, Riska, Ara Hidayat \& Meti Maspupah. (2017). "Perbandingan Model Pembelajaran Problem Solving dan Problem Based Learning terhadap Hasil Belajar Siswa pada Materi Sistem Reproduksi Manusia: Penelitian pada Siswa Kelas XI IPA SMAN 1 Ciparay Kabupaten Bandung" dalam BioEdUIN: Jurnal Program Studi Pendidikan Biologi, Vol.7, No.1 [Februari], hlm.1-12.

Mauludah, Nurul, Fenny Roshayanti \& Sumarno. (2018). "Pengaruh Model Pembelajaran Berbasis Pemecahan Masalah untuk Meningkatkan Kemampuan Literasi Lingkungan Siswa Di SMA Negeri 1 Batangan" dalam Jurnal Biologi dan Pembelajarannya, Vol.5, No.2 [Oktober], hlm.15-20. 
Maydianti, Dewi, Sutopo \& Henny Ekana Chrisnawati. (2017). "Upaya Meningkatkan Kemandirian Belajar dan Kemampuan Pemecahan Masalah Siswa melalui Model Problem Based Learning (PBL) dengan Strategi ARIAS terhadap Pembelajaran Matematika" dalam SOLUSI: Jurnal Pendidikan Matematika dan Matematika (JPMM), Vol.I, No.1 [Januari], hlm.77-98.

Melissa, M.M. (2016). "Peningkatan Kemandirian dan Prestasi Belajar Matematika dengan Pendekatan Problem Based Learning (PBL) di Kelas VII E SMPN 15 Yogyakarta" dalam Jurnal Ilmiah Edukasi Matematika, Volume 2(1). Tersedia secara online juga di: https://repository.usd.ac.id/ 6062/1/2580 Jurnal+Margaretha+Madha+JIEM.pdf [diakses di Singaraja, Bali, Indonesia: 4 November 2017].

Montgomery, Douglas C. (2013). Design and Analysis of Experiments. New York: Wiley, eighth edition.

Mukhtar, Radinal. (2015). "Hubungan Motivasi Belajar dengan Hasil Belajar pada Mata Pelajaran Seni Budaya Bidang Seni Musik Siswa Kelas X SMA Piri 1 Yogyakarta”. Skripsi Sarjana Tidak Diterbitkan. Yogyakarta: Fakultas Bahasa Dan Seni UNY [Universitas Negeri Yogyakarta]. Tersedia secara online juga di: https://eprints.uny.ac.id/18297/1/ SKRIPSI\%20RADINAL \%20MUKHTAR \%20 \%2809208241033\%29.pdf [diakses di Singaraja, Bali, Indonesia: 15 Januari 2019].

Mulyani, Nanik. (2006). Pengaruh Motivasi Berprestasi, Kontinuitas Belajar, dan Fasilitas Belajar terhadap Prestasi Belajar Siswa. Semarang: UNNES [Universitas Negeri Semarang] Press.

Mulyono. (2011). Strategi Pembelajaran Menuju Efektivitas Pembelajaran di Era Global. Malang: UIN [Universitas Islam Negeri] Maulana Malik Ibrahim Press.

Musdiani. (2019). “Analisis Model Pembelajaran terhadap Cara Mengajar Guru untuk Meningkatkan Minat Belajar Siswa pada Materi Penggolongan Hewan di Kelas V SD Negeri Pante Cermin" dalam Jurnal Tunas Bangsa, Vol.6, No.1 [Februari], hlm.60-68.

Mustofa, Wahid. (2014). "Pengaruh Suasana Belajar dan Motivasi Belajar terhadap Intensitas Belajar serta Dampaknya pada Prestasi Belajar Matematika". Skripsi Sarjana Tidak Diterbitkan. Surakarta: FKIP UMS [Fakultas Keguruan dan Ilmu Pendidikan, Universitas Muhammadiyah Surakarta]. Tersedia secara online juga di: http://eprints.ums.ac.id/31446/13/NASKAH PUBLIKASI.pdf [diakses di Singaraja, Bali,
Indonesia: 19 Desember 2018].

Nafiah, Yunin Nurun. (2014). "Penerapan Model Problem-Based Learning untuk Meningkatkan Keterampilan Berpikir Kritis dan Hasil Belajar Siswa" dalam Jurnal Pendidikan Vokasi, Vol.4, No.1 [Februari]. Tersedia secara online juga di: https://journal.uny.ac.id/index.php/jpv/article/ viewFile/2540/2098 [diakses di Singaraja, Bali, Indonesia: 19 Desember 2018].

Nainggolan, Bonifasius M.H. (2009). "Perbandingan Uji Tukey (Uji Beda Nyata Jujur (BNJ) Dengan Uji Fisher (Uji Beda Nyata Terkecil (BNT) dalam Uji Lanjut Data Rancangan Percobaan" dalam Majalah Ilmiah Panorama Nusantara, Edisi VII [Juli-Desember]. Tersedia secara online juga di: https://stein.ac.id/e-journal/pn 7/PN 2. pdf [diakses di Singaraja, Bali, Indonesia: 19 Desember 2018].

Nas, Sulastri. (2017). "Peningkatan Motivasi Belajar Matematika dalam Mengoptimalkan Kompetensi Siswa" dalam Prosiding Seminar Nasional, Vol.02, No.1, hlm.470-480.

Nuic, L., A. Sabeta \& M. Zejnelagic-Hajric. (2015). "The Effects of Problem Based Learning on Students' Achievement in Primary School Chemistry" in Bulletin of Chemists and Technologists of Bosnia and Herzegovina, Volume 44, pp.17-22. Available online also at: http://www.pmf.unsa.ba/hemija/glasnik/file/ Issue \%2044/5-17-22-Zejnilagi.pdf [accessed in Singaraja, Bali, Indonesia: 7 November 2018].

Nurbaiti, S.I., R. Irawati \& R. Lichteria. (2016). "Pengaruh Pendekatan Problem Based Learning terhadap Kemampuan Komunikasi Matematis dan Motivasi Belajar Siswa" dalam Jurnal Pena Ilmiah, Volume 1(1), hlm.1001-1010.

Nurhidayah, Dwi Avita. (2015). "Pengaruh Motivasi Berprestasi dan Gaya Belajar terhadap Prestasi Belajar Siswa pada Mata Pelajaran Matematika SMP" dalam Jurnal Dimensi Pendidikan dan Pembelajaran, Vol.3, No.2 [Juli]. Tersedia secara online di: http://journal.umpo.ac.id/index. php/dimensi/article/viewFile/83/69 [diakses di Singaraja, Bali, Indonesia: 19 Desember 2018].

Oktaviani, Mitha Arvira \& Hari Basuki Notobroto. (2014). "Perbandingan Tingkat Konsistensi Normalitas Distribusi Metode KolmogorovSmirnov, Lilliefors, Shapiro-Wilk, dan Skewness-Kurtosis" dalam Jurnal Biometrika dan Kependudukan, Vol.3, No.2 [Desember], hlm.127-135. Tersedia secara online juga di: http://journal.unair.ac.id/download-fullpapersbiometrikd8bc041810full.pdf [diakses di Singaraja, Bali, Indonesia: 19 Desember 2018].

Padmavathy, R.D. \& K. Mareesh. (2013).

"Effectiveness of Problem Based Learning in 
Mathematics" in International Multidisciplinary e-Journal, Volume 2(1), pp.45-51.

Raharjo, Heru, M. Khairudin \& Jamil Abd Baser. (2018). "The Influence of Problem Based Learning and Direct Teaching on Student's Learning Outcomes" in Jurnal Pendidikan Teknologi dan Kejuruan, Vol.24, No.1 [Mei].

Rengganis, Amalia Puspita, Pratiwi Dwijananti \& Sarwi. (2015). "Penerapan Model Pembelajaran Problem Based Learning Berbasis Inkuiri untuk Meningkatkan Penguasaan Konsep dan Keterampilan Proses Sains Siswa SMP" dalam UPEJ: UNNES Physics Education Journal, Volume 4(3), hlm.26-35.

Rosnita. (2016). "Faktor Internal dan Eksternal yang Mempengaruhi Prestasi Belajar Siswa Kelas X di MAN 1 Kota Bandung". Skripsi Sarjana Tidak Diterbitkan. Bandung: FKIP UNPAS [Fakultas Keguruan dan Ilmu Pendidikan, Universitas Pasundan].

Ruslindawati, R. (2012). "Motivasi Belajar Fisika Siswa Melalui Penerapan Pembelajaran Menggunakan LKS Non-Eksperimen pada Siswa Kelas XI IPA SMAN 5 Pekanbaru”. Skripsi Sarjana Tidak Diterbitkan. Pekanbaru: FKIP UNRI [Fakultas Keguruan dan Ilmu Pendidikan, Universitas Riau].

Rusman. (2010). Model-model Pembelajaran: Mengembangkan Profesionalisme Guru. Jakarta: PT Raja Grafindo Persada.

Saefullah, A., P. Siahaan \& I.M. Sari. (2013). "Hubungan antara Sikap Kemandirian Belajar dan Prestasi Belajar Siswa Kelas X pada Pembelajaran Fisika Berbasis Portofolio" dalam WAPFI: Wahana Pendidikan Fisika, Vol.1, No.1. Tersedia secara online juga di: http://ejournal.upi. edu/index.php/WapFi/article/view/4891 [diakses di Singaraja, Bali, Indonesia: 15 Januari 2019].

Sanjaya, Wina. (2006). Strategi Pembelajaran Berorientasi Standar Proses Pendidikan. Jakarta: Kencana Perdana Media

Saptono, Johanes Joko. (2016). "Motivasi dan Keberhasilan Belajar Siswa" dalam Regula Fidei, Vol.I, No.1 [Februari], hlm.189-212.

Sardiman, A.M. (2006). Interaksi dan Motivasi Belajar-Mengajar. Jakarta: CV Rajawali.

Sari, Berti Okta, Mardiyana \& Dewi Retno Sari Saputro. (2015). "Eksperimentasi Model Pembelajaran Problem Based Learning (PBL), Discovery Learning (DI), dan Cooperative Learning (CL) Ditinjau dari Kecerdasan Interpersonal Siswa" dalam Jurnal Elektronik Pembelajaran Matematika, Volume 3(6), hlm.587-598.

Satrianingsih, Cici Juni Puput, Sri Haryani \& Novi Ratna Dewi. (2017). "Model Pembelajaran
Berbasis Masalah Berbantuan Science Pocket Book untuk Meningkatkan Kemampuan Kognitif dan Sikap Terhadap Sains" dalam JISE: Journal of Innovative Science Education, Volume 6(2), hlm.273-281.

Sawitri, I., Suparmi \& N.S. Aminah. (2016). "Pembelajaran Fisika Berbasis Problem Based Learning (PBL) Menggunakan Metode Eksperimen dan Demonstrasi Ditinjau dari Kemampuan Berpikir Kritis tehadap Prestasi Belajar dan Keterampilan Metakognitif" dalam Jurnal Inkuiri, Volume 5(2), hlm.79-86. Tersedia secara online juga di: http://jurnal.fkip.uns. ac.id/index.php/sains diakses 4 November 2017. [diakses di Singaraja, Bali, Indonesia: 7 November 2018].

Selcuk, G.S. (2013). “A Comparison of Achievement in Problem Based, Strategic, and Traditional Learning Classes in Physics" in International Journal on New Trends in Education and Their Implications, Vol.4, No.1.

Sidik, Moch Ilham \& Hendri Winata. (2016). "Meningkatkan Hasil Belajar Siswa melalui Penerapan Model Pembelajaran Direct Instruction" dalam JP MANPER: Jurnal Pendidikan Manajemen Perkantoran, Vol.1, No.1 [Agustus], hlm.49-60.

Simanjuntak, Wanti. (2015). "Faktor-faktor yang Mempengaruhi Prestasi Belajar" dalam KOMPASIANA: Byond Blogging, pada 24 Juni. Tersedia secara online juga di: $\underline{\text { htps:// }}$ www.kompasiana.com/ wantisimanjuntak/ 552e34eb6ea83482208b456d\% 20\%20\%5B14/ faktor-faktor-yang-mempengaruhi- prestasibelajar [diakses di Singaraja, Bali, Indonesia: 2 Desember 2018].

Slameto. (2003). Belajar dan Faktor-faktor yang Mempengaruhi. Jakarta: Rineka Cipta.

Sugiyanto. (2009). “Kontribusi Motivasi Berprestasi terhadap Prestasi Akademik Siswa Kelas XI SMAN 10 Semarang" dalam Paradigma, Volume 8(4), hlm.19-34. Tersedia secara online juga di: http://media. neliti.com [diakses di Singaraja, Bali, Indonesia: 12 Mei 2018].

Sudjana, D. (2005). Metode dan Tehnik Pembelajaran Partisipatif. Bandung: Falah Production.

Sugiyanto. (2007). "Pentingnya Motivasi Berprestasi dalam Mencapai Keberhasilan Akademik Siswa". Tersedia secara online di: http://staff.uny.ac.id/ sites/default/files/ penelitian/ sugiyanto-mpd/ pentingnya-motivasi-berprestasi-dalammencapai-keberhasilan- akademik-siswa. pdf [diakses di Singaraja, Bali, Indonesia: 19 Desember 2018].

Sumarsono, Joko. (2009). Fisika: Untuk SMA/MA 
Kelas X. Jakarta: Pusat Perbukuan Depdiknas RI [Departemen Pendidikan Nasional Republik Indonesia], editor Diyah Nuraini. Tersedia secara online juga di: https://bsd.pendidikan. id/data/SMA 10/Fisika Kelas 10 Joko Sumarsono 2009.pdf [diakses di Singaraja, Bali, Indonesia: 2 Desember 2018].

Suparno, Paul. (2013). Miskonsepsi dan Perubahan Konsep dalam Pendidikan Fisika. Jakarta: Grasindo.

Susilonuringsih, Kukuh. (2006). "Pengaruh Faktor Intern dan Faktor Ekstern terhadap Minat Belajar Siswa Kelas I di SMK Yayasan Pendidikan Ekonomi (YAPEK) Gombong Tahun Diklat 2005/2006”. Skripsi Sarjana Tidak Diterbitkan. Semarang: Jurusan Ekonomi, Fakultas Ilmu Sosial UNNES [Universitas Negeri Semarang]. Tersedia secara online juga di: https://lib.unnes. ac.id/2344/1/1507.pdf [diakses di Singaraja, Bali, Indonesia: 2 Desember 2018].

Sutama, Eko Wahyudiyanto \& Sabar Narimo. (2017). "Dampak Motivasi Berprestasi terhadap Kemandirian Belajar Matematika di Sekolah Menengah Pertama" dalam Jurnal Managemen Pendidikan, Vol.12, No.2 [Juli], hlm.191-200.

Tukey, John. (1949). “Comparing Individual Means in the Analysis of Variance" in Biometrics, Volume 5(2), pp.99-114.

Ulfa, Farida Maria \& Maya Asriana. (2018). "Keefektifan Model PBL dengan Pendekatan Open-Ended pada Pencapaian Kemampuan Berpikir Kreatif Matematis dan Disposisi Matematis Siswa" dalam PRISMA: Proseding Seminar Nasional Matematika, Volume 1, hlm.289-298.

Wardhani, K. (2012). "Pembelajaran Fisika dengan Model Problem Based Learning Menggunakan Multimedia dan Modul Ditinjau dari Kemampuan Berpikir Abstrak dan Kemampuan Verbal Siswa" dalam Jurnal Inkuiri, Vol.1, No.2.

Wasonowati, R.R.T. (2014). "Penerapan Model Problem Based Learning (PBL) pada Pembelajaran Hukum-hukum Dasar Kimia Ditinjau dari Aktivitas dan Hasil Belajar Siswa Kelas X IPA SMA Negeri 2 Surakarta Tahun Pelajaran 2013/2014" dalam Jurnal Pendidikan
Kimia, Vol.3, No.3.

Watanabe, M. et al. (2013). "The Effects of Using Direct Instruction to Teach Coin Counting and Giving" in International Journal of Basic and Applied Science, Vol.02, No.01, pp.150-159.

Wenno, H. (2014). "Direct Instruction Model to Increase Physical Science Competence of Students as One Form of Classroom Assesment" in International Journal of Evaluation and Research in Education, Vol.3, No.3, pp.169-174.

Widowati, S., H. Susanto \& A. Yulianto. (2013). "Pengaruh Pembelajaran Kooperatif Tipe Group Investigation Berbasis Eksperimen Inkuiri terhadap Motivasi Belajar Siswa" dalam UPEJ: UNNES Physics Education Journal, Volume 2(2), hlm.13-18.

Williams, Lynne J. \& Herve Abdi. (2010). "Fisher's Least Significant Difference (LSD) Test" in Neil Salkind [ed]. Encyclopedia of Research Design. Thousand Oaks, CA: Sage. Available online also at: https://www.utd.edu/ herve/abdi-LSD2010pretty.pdf [diakses di Singaraja, Bali, Indonesia: 19 Desember 2018].

Wiyono, Heri. (2017). "Peningkatan Kemandirian Belajar Matematika melalui Strategi PBL pada Siswa SMP”. Skripsi Sarjana Tidak Diterbitkan. Surakarta: Program Studi Pendidikan Matematika FKIP UMS [Fakultas Keguruan dan Ilmu Pendidikan, Universitas Muhammadiyah Surakarta]. Tersedia secara online juga di: http:// eprints.ums.ac.id/59267/15/NASKAH\%20 PUBLIKASI-libraryums heri\%20wiyono. pdf [diakses di Singaraja, Bali, Indonesia: 2 Desember 2018].

Yankie, Badriah. (2018). "Refleksi untuk Meningkatkan Kualitas Pembelajaran" dalam KOMPASIANA: Byond Blogging, pada 14 Januari. Tersedia secara online juga di: https://www.kompasiana.com/ yang/5a5aefdcdcad5b064f576362/refleksi-untukmeningkatkan-kualitas-pembelajaran [diakses di Singaraja, Bali, Indonesia: 15 Januari 2019].

Yusuf, A. Muri. (2014). Metode Penelitian Kuantitatif, Kualitatif \& Penelitian Gabungan. Jakarta: Penerbit Kencana. 